\title{
SPIRIT AND ECOLOGY IN THE CONTEXT OF AFRICAN THEOLOGY
}

\author{
Teddy Chalwe Sakupapa \\ United Church of Zambia Theological College \\ University of the Western Cape
}

\begin{abstract}
This contribution seeks to map a possible trajectory for an African theological response to the debate on the ecological crisis. The author is in tandem with scholars who argue that Christian doctrine can provide theologians with resources to enable a theological response to the ecological debate. Therefore, proceeding from the perspective of a contextual theological methodology, it will be argued that one way in which African theology can contribute towards the cultivation of an ecological ethos in African Christianity lies in the appropriation of the conceptual framework of the African notion of vital force in the articulation of pneumatology within the context of African theology. The author contends that life-centeredness and relationality, as expressed by the African notion of vital force, have ecological significance.
\end{abstract}

Key Words: Vital Force, Ecology, African Pneumatology, Salvation, African Theology, African Pentecostalism, African Traditional Religion

\section{Introduction}

It has been argued by some scholars that traditional Christian doctrine has played a major role in the present ecological/environmental crisis. According this view, the traditional interpretation of the doctrine of creation in general and that of Christian anthropology in particular, have to a greater extent exalted the place of the human in creation resulting in the view of the rest of creation as being in the service of humans. On the contrary, there is a growing cohort of theologians who argue that Christian doctrine can offer important resources for a theological response to the debate on the present ecological crisis (see Conradie 2004; Bergmann 2005; Edwards 2006; Jensen 2008). The doctrine of the Holy Spirit has been especially explored in this regard (cf. Bergmann 2005; Wallace 2001; Muller-Fahrenholz 1995). While much fruitful engagement of Christian doctrine in ecological discussions has arisen in this vein and usually from within the context of Western theological tradition(s), African theology is yet to sufficiently engage Christian doctrine for purposes of addressing the ecological crisis from the vantage point of the African context.

In affirming with those who underscore the relevance of the doctrine of the Holy Spirit in an attempt to offer a theological response to the ecological crisis, this article argues for the appropriation of the African notion of vital force in the articulation of pneumatology in the context of African theology (cf. Daneel 1992). While embracing an inculturation methodology, I am at the same time in agreement with Fulljames (2003) that "there can be a significant contribution to the development of Christian theology in one cultural context from interaction with theologies developed in other cultural contexts" (Fulljames 2003). This underscores the view that contextual theology is at the same time glocal. In light of 
this, it is plausible to argue that theological insights from one context can be engaged with those arising from other contexts as I will attempt to show in this article.

Structurally therefore, I will first give a brief reflection on the neglect of pneumatology in much of African theology. Particular attention will be devoted to a brief analysis of the pneumatology of African Pentecostalism. This will be followed by a brief analysis of the notion of vital force. Finally, I will attempt to point out the ecological significance of pneumatology articulated within the conceptual framework of vital force.

\section{Pneumatology in African Theology}

Pneumatology as a subject for theological reflection has been largely neglected in much of African theology. Charles Nyamiti (1994:63) has defined African Christian theology as "the understanding and expression of the Christian faith in accordance with African needs and mentality" (cf. Ukpong 1984:7). Generally, five trends can be distinguished within African theology namely, inculturation theology, liberation theology, black theology, African women's theology and reconstruction theology. Within the context of these trends, African theologians have done considerable work on themes such as the Bible, African religion, inculturation, liberation, Christology, ethics, ecumenism and more recently on justice, reconciliation and health. However, the subject of pneumatology has been generally neglected in much of African theology.

At the ecclesial level, the mainline churches in Africa, both Roman Catholic and Protestant, have continued to perpetuate the general tendency which was predominant among Western missionaries in the $20^{\text {th }}$ century, of "assigning the Holy Spirit primarily an instrumental function in faith and in ecclesial existence, and thus confining the Spirit to a fundamentally domestic rather than cosmic role" (Rosato 1981:160). As for the African independent Churches (AIC's), the Holy Spirit came to take centre stage in their belief system (Nganda \& Mofokeng 2001:23). However, some scholars have charged that the popular theology of the AIC's does not draw distinctions between the Christian doctrine of Holy Spirit and the concept of power in African traditional thought (see Sundkler 1961:244). Similarly, the kind of Christianity, which is rapidly expanding in much of subSaharan Africa today, places emphasis on the understanding of the Holy Spirit as power (Anderson 1991). Following Allan Anderson's (2010) classification of Pentecostalism, I will in what follows refer to this brand of African Christianity as African Pentecostalism. It is necessary here to deal with African Pentecostalism given the fact that is becoming implausible to speak of the African theological inculturation discourse without having to deal with the African Pentecostal phenomena. For as Nigerian theologian Ogbu Kalu (2002:136) has lucidly argued, African "Pentecostalism is a form of African Christianity rooted in African primal religiosity." And more recently, Kalu (2008:186) has further observed that African "Pentecostalism has produced a culture of continuity by mining primal worldview, reproducing an identifiable character, and regaining a pneumatic and charismatic religiosity that existed in traditional society".

In African Pentecostalism, the Holy Spirit is understood as the power that overcomes all manner of problems in the lives of believers. This conception of the Holy Spirit, couched as it is in a particular soteriological discourse, has been attractive to many people in Africa for a variety of reasons. According to some specialists on African Pentecostalism, this attraction is to be attributed to these churches' appropriation of the salvific discourse of African traditional religion in their teachings (Kalu 2008:186). In the worldview of African religion, life is often explained with reference to religion and the spirit world (Pobee 1996:10). For instance, 
phenomena such as birth, death, illness, infertility, drought, road accidents, thunderstorm, and harvest among others, are explained as purposive acts of spiritual forces, evil or benevolent. Underlying this view is the belief that humans are vulnerable and open to spiritual forces for ill or good. No wonder then that salvation is perceived as freedom from spiritual powers, which limit or hinder human beings from attaining their well-being. Thus, in African religion salvation has to do with physical and immediate dangers that threaten individual or community survival, good health, and general prosperity or safety (Mbiti 1974:112). It is an immanent concern. Mbiti (1974:113) thus argues, "as understood through African religious experiences in the traditional setting, salvation is either past or present." That is to say, blessings from God and the ancestors are sought for this life. Furthermore, fullness of life is understood in terms of material well-being.

Similar to African traditional religion, African Pentecostalism emphasises a thisworldly perspective on salvation. Material prosperity is interpreted as the stamp of divine blessing. This view of salvation clearly resonates with African traditional religion's soteriological discourse as highlighted above. Furthermore, the understanding of prayer in much of African Pentecostalism signals an African traditional worldview of causality. Larbi (2002:143) is therefore correct when he asserts that the success of Pentecostalism in Africa is, among other things, "largely due to their ability to place the traditional understanding of the cosmic struggle in the realm of Christian belief." Within such an understanding of reality, the Holy Spirit is portrayed "as the all-embracing, pervading power of God" that can meet the existential needs of the Africans (Anderson 1990:73). It is presented as the power that overcomes all other malevolent powers.

On closer analysis, however, the African Pentecostals' appropriation of the worldview of African traditional religions and the accompanying portrayal of the Holy Spirit in terms of power is problematic. In my view, their appropriation of the salvific discourse of African traditional religion is uncritical. It also contributes to an anti-scientific attitude among its members. For to only present the Holy Spirit as the power that overcomes all other forces is not adequate to address the challenges facing African Christians today. The challenges of corruption, ecological degradation, HIV/AIDS, ethnicity, illiteracy, and unemployment, to mention a few, require much more than a concept of the Spirit as power. Furthermore, this emphasis on power is problematic when viewed in the light of both the biblical message of the cross and Africa's challenges related to political power as the history of dictatorship, coups and escalating levels of corruption in some African countries show (see Anderson 1991:58; Katongole 2011:47). The pneumatology of African Pentecostalism also tends to focus more on the individual quest for welfare much to the neglect of societal needs and the care of the earth. Hence, scholars such as David Ngong (2010:2) point an accusing finger at African Pentecostal pneumatological soteriology as contributing "to the perpetration of capitalistic greed and the widening of the gap between the rich and the poor."

In my view therefore, the appropriation of the salvific discourse of African traditional religion in the mainly oral theology of African Pentecostalism is not conducive for the cultivation of the mindset necessary for the development of the African continent, as well as the cultivation of an ecological ethos.

In spite of the recent interest on pneumatology incited as it is by the recent proliferation of African Pentecostalism, African theologians are yet to articulate a pneumatology that addresses the needs of the African. Apart from a recent monograph by David Ngong (2010) in which he has problematised the claim of African Pentecostalism as meeting the needs of African people vis-à-vis what Africa is and can be. As insightful as Ngong's work is, it does not sufficiently engage the cultural and intellectual infrastructure of the African 
religious experience. There is therefore a need for a relevant articulation of African pneumatology. In my view, a relevant pneumatology for the African context is possible if, in our articulation of pneumatology, we critically appropriate the African notion of lifecenteredness as expressed by the concept of vital force.

\section{The Notion of Vital Force}

Vital force is a traditional African notion of being in which God, ancestors, humans, animals, plants and minerals are understood in terms of force or vital energy (Tempels 1959:31). This notion is not a peculiarly African concept. Similar notions can be traced in non-African societies albeit differently nuanced. Such notions include prana among the Hindus, mana among the Hawaiians, gi among the Koreans, $q i$ or chi among the Chinese, and $k i$ among the Japanese (see Thele 2005:54; Kim 2007). In early twentieth century Europe, the French philosopher Henri Bergson (1859-1941) introduced a notion of vital force as an élan vital. He postulated a concept of an all-pervading vital impetus, an élan vital, which according to him was the principle behind evolution and the development of organisms. By emphasising the élan vital, Bergson was expressing his skepticism of mechanistic models of nature prevalent during his time (Bennett 2010:xvii). He was specifically against the inadequacy of neo-Darwinian theories of the early 1900's to explain the source of new biological forms in the context of the evolution theory. Bergson framed his discussion of vital force within the framework of vitalist concepts of nature associated with nineteenth-century Romanticism.

As an African notion of being and Bantu concept of the world, the notion of vital force was first extensively dealt with by the Belgian Franciscan missionary, Placide Tempels in his Bantu Philosophy (1959). In this text, originally written in Flemish, Tempels attempted to identify the basic principles, which influenced the life and behaviour of the Baluba of presentday Democratic Republic of Congo, a Bantu group among whom he worked as a missionary between 1930 and 1962. Tempels was seeking, in part, to find a conceptual framework on which the evangelisation of the Luba people could be based. In his view, vital force is the unifying notion that underlies Bantu cosmology, ethics and ritual. He opined that the notion of vital force as found among the Bantu includes of necessity all beings, namely: God, the living dead, humans, animals, plants and minerals (Tempels 1959:36). It is understood in terms of potent life or life energy. "Force, the potent life, vital energy", Tempels (1959:31) argued, "is the object of prayers and invocations to God, to the spirits and to the dead, as well as of all that is usually called magic, sorcery or magical remedies".

Operating as he did from within the framework of the then prevalent Neo-Thomistic philosophical framework, Tempels argued that Bantu ontology perceives being as force or power (cf. Schreiter 1985:9). He came to the conclusion that "the fundamental notion under which being is conceived, lies within the category of forces" (Tempels 1959:33). For the Bantu, Tempels (1959:34) argued, 'force' is conceived as a necessary element in 'being' and is inseparable from the definition of 'being'. For Tempels therefore, the Bantu conceive force as being more than a necessary attribute of being. They "speak, act, live as if for them, beings were forces ... Force is the nature of being, force is being, being is force" (Tempels 1959:35). Tempels thus claimed the inseparability of force from being in Bantu thought. Moreover, he compared the European conception of being with that of the Bantu and concluded that what Europeans call being, the Bantu conceive as force (Tempels 1959:35). Accordingly, Tempels argued that the Bantu concept of being is essentially dynamic while that of Europeans is static. 
Cosmologically, Tempels held that the Bantu conceive the world as a hierarchically ordered cosmos in which a hierarchy of forces is to be found. He categorised different forces in the order God, human, animal, vegetable and mineral. He argued that the hierarchy among the different forces is based on "vital power, rank and primogeniture" (Tempels 1959:43). Thus, "above all force is God, Spirit and Creator, the mwine bukomo bwandi. It is he who has force, power, in himself. He gives existence, power of survival and of increase, to other forces" (Tempels 1959:41). In this regard, God is conceived as the great One, the great Force and source of force for every creature (Tempels 1959:31). He is the 'great Muntu', the 'great person' the 'great, powerful Life Force' (Tempels 1959:37).

Tempels' articulation of Bantu Philosophy in general and his notion of vital force in particular have, however, elicited varying responses from African theologians and philosophers. His critics have often raised the following criticisms. Firstly, he is accused of having argued for a distinct African way of thinking, thus promoting the cult of difference (Ngong 2010:77). Secondly, some have questioned whether or not Tempels notion of vital force is indeed an African notion (Mbiti 1969:10). And thirdly some thinkers have accused Tempels of having generalised the notion of vital force to all African peoples (Wiredu 1998).

Tempels' broad thesis of vital force is, as Okafor (1982:89) argues, "methodologically on the right track towards uncovering of the inner structure of African cosmology." In my view, Tempels' thesis does bring to the fore the centrality of life and the interaction or interrelatedness of beings in the African worldview. Clearly, these are themes which have been elaborated upon quite extensively by many African thinkers, theologians and philosophers alike. For instance, Mbiti (1990:106) has underscored the centrality of community (inter-relatedness) in the African worldview when he states that an individual can only say that "I am because we are: and since we are therefore I am." Vincent Mulago (1969) has equally underscored the centrality of community among Africans through his notion of vital union. By vital union, Mulago refers to 'participation in the common life'; "a relationship of being and life between each individual and his descendants, his family, his brothers and sisters in the clan, his antecedents, and also with God, the ultimate source of all life" (Mulago 1969:138). In my view, therefore, to the extent that Tempels' thesis of vital force highlights the concerns of the Bantu and how they interpret reality, it is a conceptual framework of Bantu ontology and cosmology. This point is further buttressed by the fact that the notion of vital force has been appropriated and re-interpreted by several African theologians and philosophers (Nkurunziza 1989; Magesa 1997, 2004; Nkemnkia 1999; Nyamiti 1976; Kagame 1956).

The conceptual framework of Bantu ontology and cosmology as articulated by Tempels and re-interpreted and appropriated by African theologians, indicates a strong sense of respect for life. From this, one could argue that a conceptual framework of vital force is one which highlights the centrality of life and the inter-relatedness of beings (community). Within such a framework, the whole of reality is understood as inter-related, without any separation between the sacred and the secular. Crucially, life is regarded as the highest value (Nkurunziza 1989:129; Okafor 1982:91). It is understood as life-in-relationship (Nkurunziza 1989:126). In other words, relationality is at the heart of African ontology.

Accordingly, the conceptual framework of vital force presents a view of God as the giver and source of all life (Tempels 1959:31). From a theological point of view therefore, it could be argued that vital force is the power of God present in all creation and without which life is not possible. Analogically therefore, it can be construed that vital force is the Spirit of God understood as the principle of life and enabler of communion within creation. Such an interpretation highlights the idea that the whole of reality is pervaded by God's vital force, which makes life possible in its inter-relatedness and interdependence. The emphasis here of 
speaking about the Holy Spirit as the vital force analogically takes into account the dilemma of language in God talk. For as Geisler Norman (1988:219) has put it, "Religious language has two basic hazards. It must avoid verbal idolatry on the one hand and experiential emptiness on the other hand. If it is overly transcendent, it departs from an experiential basis for meaning. If it is completely immanentistic, it commits semantic atheism."

In view of the abovementioned observations, I propose that the notion of vital force can indeed provide a conceptual framework for articulating relevant pneumatology in the context of African theology. This is crucial for even biblical and classical metaphors of spirit such as ruach (Hebrew), pneuma,(Greek) and spirare (Latin) represent spirit "as a fluid, pervasive, intangible energy whose fundamental quality is vitality and freedom and whose fundamental purpose is to create, shape, and enliven" (Hodgson 1994:277).

In my view, the notion of vital force provides a conceptual framework for articulating pneumatology that is relevant to the context, faithful to biblical witness and also accountable to the wider Christian community (ecumenical perspective). This is critical given that the notion of vital force provides a conceptual framework in which life and relationality are emphasised. Both life and relationality are central themes in scripture as well as in recent pneumatological reflections by theologians such as Jurgen Moltmann and Denis Edwards (cf. Dunn 1998). Relationality has also become very central in discourses on the Trinity and ecology in recent times. This perspective points to the relational nature of all reality as Denis Edwards so emphatically asserts. In a similar fashion albeit not identical, Sigmund Bergmann sees in the Trinitarian concept of God a convergence with the ecological concept of nature without the two necessarily becoming congruent. He thus writes, “.... an understanding of the communality of God's being discloses new possibilities for interpreting the relational being of nature" (Bergmann 2005:283). In Jurgen Moltmann's reflections, this can be understood in terms of his social doctrine of the trinity and its implications on his ideas about the cosmic dimension of the Spirit.

This emphasis on the cosmic Spirit has been taken quite seriously in recent discourses on pneumatology. For instance, Swedish theologian Krister Stendahl (1990:49) has spoken of the Spirit of God as being present and dynamic within the global household as the 'energy for life', the whole life of our planet. Others such as Mark Wallace (2001) have, with a biocentric focus, introduced a new metaphor for the Spirit as the 'Green Face of God' on the basis of biblical nature imagery which depict the Spirit as vivifying breath (Gen 1:2, Ps 104:29-30), healing wind (Judges 6:34, John 3:6, Acts 2:1-4), living water, and the divine dove. American theologian Elizabeth Johnson (1993:42ff) also stresses the cosmic dimension of the Spirit when she asserts that the Spirit is "the dynamic flow of divine power that sustains the universe, bringing forth life". She argues that this 'indwelling, renewing, moving' Creator Spirit is the source of novelty in creation and of the communion between all creatures. In his Winds of the Spirit American, Peter Hodgson adds his voice to these discourses through his portrayal of the Spirit as creative and alluring cosmic eros. Expounding on this, Hodgson (1994:194) writes, "God's love for the world is erotic in the sense that God creates, desires, and allures the world in its vitality and materiality, while at the same time transfiguring that materiality into relationships of spirituality, that is, of inwardness, recognition, mutuality, self-giving."

In brief, pneumatology that is articulated within the conceptual framework of vital force will:

- understand the Spirit within the context of the Trinity

- understand the Holy Spirit as the enabler of communion

- it will highlight the cosmic breadth of the work of the Holy Spirit as well as the eschatological dimension of the Christian faith 
- it will understand the work of the Spirit as active in efforts which support life including scientific innovations, works of justice and quests for wisdom.

\section{Pneumatology and Ecology}

The third point above is especially important for developing an ecological ethos for the African context. As Jurgen Moltmann (1992:34) opines, through the Holy Spirit, God is present in all things and all things are in God. With this in mind, it is plausible to argue that the Holy Spirit is not solely the Spirit of redemption but also that of creation. That is to say, the work of the Spirit should not be interiorised to the church and the individual believer as much of Christian theology seems to argue; rather it must include the whole of creation (cf. Moltmann 1992:8).

In my view, the African notion of vital force opens up avenues for reflection on the cosmic breadth of the Spirit given its emphasis on life and relationality. Recent perspectives on the relational nature of all reality buttress the African perception on reality as interrelated. In light of the conceptual framework of vital force therefore, it can be argued that the Holy Spirit will be understood as the vital force and life that is common to all. In other words, the Spirit's presence will be recognised in the whole of creation in a panentheistic sense. This perspective is particularly important in getting African Christians and churches involved in ecological work. In fact, in African cosmology, the sacredness of nature is derived from nature's relationship with the creator whose vital force has animated nature. Humans are therefore in an ontological relationship with nature given their common descent from the creator. A pneumatological understanding of vital force enhances this ontological relationship as this article proposes. As such, one of the ways in which to respond to the ecological crisis in the African context lies in the recovery of the African notion of vital force with its underlying idea of God's pervading presence in the whole of creation. The notion of vital force can therefore be exploited for the development of an ecological ethos based on reverence for the whole of life. Theologian Mark Wallace (2001:445) has similarly argued, "that hope for a renewed earth is best founded on belief in the Spirit as the divine force within the cosmos who continually works to sustain all forms of life." Wallace argues for the understanding of the Spirit not as a metaphysical entity but as a healing life force, which engenders human flourishing as well as the welfare of the planet. In the face of the environmental crisis in Africa, therefore, it is my contention that a helpful response would lie in the recovery of the Holy Spirit as God's power of life-giving breath (ruach) - the vital force - who indwells and sustains all life forms.

Such articulation should, however, recognise the eschatological dimension of the Christian understanding of salvation. Thus, African theology will not only emphasise salvation as an immanent concern, but also as an eschatological reality. In other words, while the material must be stressed especially in the African context, the Christian understanding of salvation is not only limited to the material and this worldly understanding of salvation. In this regard, the Spirit will be understood as "the eschatological power by which the present age will be transformed into the kingdom of God" (Peters 2000:243). That is to say, it will be through the Spirit that life, justice and peace for the whole of creation will be established and remain undisturbed (cf. Peters 2000:243). The ultimate well-being of all will be realised in the eschaton.

\section{Conclusion}

In this article it was pointed out that pneumatology has been a neglected subject in much of African theology. Accordingly, an attempt has been made to argue for the utilisation of the conceptual framework of vital force for the articulation of pneumatology in the context of 
African theology. In the view of this author, such articulation could make a significant contribution towards enhancing positive attitudes towards nature. This places the emphasis of the notion of vital force on life and relationality. In this regard therefore, the notion of vital force can be explored as an eco-pneumatological concept. Indeed, African theology has the potential to contribute to the discourse on Christian responses to the ecological crisis if it can articulate pneumatology that takes into account the African intellectual and cultural infrastructure in its theologising. The articulation of how such an ecological pneumatology would look like is a task for further research.

\section{BIBLIOGRAPHY}

Anderson, A 1991. Moya: The Holy Spirit in an African Context. Pretoria:

University of South Africa.

Anderson, A 1992. Bazalwane: African Pentecostals in South Africa. Pretoria:

University of South Africa.

Anderson, A et al., (eds.) 2010. Studying Global Pentecostalism: Theories and Methods.

Los Angeles: University of California Press.

Bennett, J 2010. Vibrant Matter: A Political Ecology of Things. Duke University Press.

Bergmann, S 2005. Creation set free: The Spirit as Liberator of nature.

Grand Rapids Michigan: William B Eerdmans Publishing Company.

Bergson, H 1983. Creative Evolution. Translated by Arthur Mitchell. Lanham, HD:

University Press of America.

Conradie, EM 2004. An Ecological Christian Anthropology: At Home on Earth?

Aldershot, England: Ashgate.

Daneel, ML 1992. "African Independent Church Pneumatology and the Salvation of

All Creation," Theologia Evangelica 25:1. 35-55.

Dunn, JDG 1998. The Christ \& The Spirit. Edinburgh: T\&T Clark.

Edwards, D 2006. Ecology at the Heart of Faith. MaryKnoll, New York: Orbis Books.

Fulljames, P 1993. God and Creation in Intercultural Perspective: Dialogue between the

Theologies of Barth, Dickson, Pobee, Nyamiti and Pannenberg. New York: Peter Lang.

Geisler, N \& Corduan, W 1988. Philosophy of Religion. Grand Rapids: Baker Book House.

Hodgson, PC 1994. Winds of the Spirit: A Constructive Christian Theology. London: SCM Press.

Jensen, DH 2008. The Lord and Giver of Life: Perspectives on Constructive Pneumatology.

Westminster: John Knox Press.

Johnson, E 1993. Women, Earth, and Creator Spirit. New York: Paulist Press.

Kagame, A 1956. La Philosophie Bantu-Rwandaise de l'être. Bruxelles: Academie Royale des Sciences Coloniale.

Kalu, O 2002. Preserving a Worldview: Pentecostalism in the African Maps of the

Universe. In: Pneuma 24/1 (2002). 110-137.

Kalu, O 2008. African Pentecostalism: An Introduction. New York:

Oxford University Press.

Katongole, E 2011. The Sacrifice of Africa: A Political Theology for Africa. Grand Rapids, Michigan: William B. Eerdmans Publishing Company.

Kim, G 2007. The Holy Spirit, Chi, and the Other: A Model of Global and Intercultural Pneumatology. New York: Palgrave Macmillan.

Larbi, K 2002. African Pentecostalism in the Context of Global Pentecostal Ecumenical Fraternity: Challenges and Opportunities. In: Pneuma, 24/2 (2002). 138-166.

Magesa, L 1997. African Religion: The Moral Traditions of Abundant Life. New York:

Orbis Books. 
Mbiti, J 1969. African Religions and Philosophy. Oxford: Heinemann.

Mbiti, J 1974. Some Reflections on African Experience of Salvation Today. In: Samartha, SJ (ed.). Living Faiths and Ultimate Goals: A Continuing Dialogue. Geneva:

World Council of Churches. 108-119.

Mbiti, JS 1990. African Religions and Philosophy. Oxford: Heinemann.

Moltmann, J 1992. The Spirit of Life: A Universal Affirmation. Philadelphia: Fortress Press.

Mulago, V 1969. Vital participation: The Cohesive Principle of the Bantu community.

In: Dickson, KA \& Ellington, P (eds.). Biblical Revelation and African Beliefs.

London: Lutterworth Press.

Muller-Fahrenholz, G 1995. God's Spirit: Transforming a World in Crisis. Geneva:

WCC Publications.

Nganda, HN \& Mafokeng, EK 2001. African Christian Witness: African Indigenous

Churches. Pietermaritzburg: Cluster Publications.

Ngong, D 2010. The Holy Spirit and Salvation in African Christian Theology: Imagining a more hopeful future for Africa. Oxford: Peter Lang.

Nkemnkia, MN 1999. African Vitalogy: A Step Forward in African Thinking.

Nairobi: Paulines Publications Africa.

Nkurunziza, DRK 1989. Bantu Philosophy of Life in the light of the Christian Message:

A Basis for an African Vitalistic Theology. New York: Peter Lang.

Nyamiti, C 1976. African Tradition and the Christian God. Eldoret: Gaba Publications.

Nyamiti, C 1994. Contemporary African Christologies: Assessment and Practical sugges-

tions. In: Gibbelini, R (ed.). Paths of African Theology. London: SCM Press. 62-77.

Okafor, SO 1982. Bantu philosophy: Placide Temples Revisited. In: Journal of Religion in Africa 13/2. 83-100.

Peters, T 2000. God- The Worlds Future: Systematic Theology for a New Era.

Minneapolis: Fortress Press.

Pobee, J 1996. West Africa: Christ would be an African Too. Geneva: WCC.

Rosato, JP 1981. The Spirit as Lord. The Pneumatology of Karl Barth. Edinburgh:

T\&T Clark Ltd.

Schreiter, RJ 1985. Constructing Local Theologies. London: SCM.

Stendahl, K 1990. The Energy of Life: Reflections on the Theme "Come Holy Spirit-

Renew the Whole Creation.” Geneva: WCC Publications.

Tempels, P 1959. Bantu Philosophy. Paris: Editions Réclame.

Thele, NR 2005. Relation, Awareness, and Energy - Three Languages, Three Worlds. In:

Jeanrond, WG \& Lande, A (eds.). The Concept of God in Global Dialogue. New

York: Orbis Books. 48-62.

Ukpong, J 1984. African Theology: A profile. Spearhead no. 80. Eldoret: Gaba Publications.

Wallace, M 2001. The Green Face of God: Recovering the Spirit in an Ecocidal Era. In: Hinze,

B \& Dabney, L (eds.). Advents of the Spirit: An Introduction to the Current Study of

pneumatology. Milwuakee, Wisconsin: Marquette University Press. 442-462.

Wiredu, K 1998. Toward Decolonizing African Philosophy and Religion. In:

African Studies Quarterly| Volume 1, Issue 4. 